\title{
Temperature adaptation of microbial communities in different horizons of Siberian permafrost-affected soils from the Lena Delta
}

\author{
K. Mangelsdorf ${ }^{\mathrm{a}, *}$, E. Finsel ${ }^{\mathrm{b}}$, S. Liebner ${ }^{\mathrm{c}}$, D. Wagner ${ }^{\mathrm{c}}$ \\ ${ }^{a}$ Helmholtz Centre Potsdam GFZ German Research Centre for Geosciences, Telegrafenberg, 14473 Potsdam, Germany \\ ${ }^{\mathrm{b}}$ Freie Universität Berlin, Kaiserswerther Str. 16/18, 14195 Berlin, Germany \\ ${ }^{c}$ Alfred Wegener Institute for Marine and Polar Research, Research Unit Potsdam, Telegrafenberg, 14473 Potsdam, Germany
}

Received 20 June 2008; accepted 23 February 2009

\begin{abstract}
The cell membrane phospholipid (PL) inventory of microbial populations in a Siberian permafrost soil of the Lena Delta was analysed to examine as to how the microbial populations within different horizons of the active layer were adapted to the extreme temperature gradient in this environment. One surface-near and one permafrost-near soil sample were taken from the active layer on Samoylov Island in the southern central Lena Delta (Siberia) and in each case incubated at 4 and $28^{\circ} \mathrm{C}$. Subsequently, the phospholipid cell membrane composition of the indigenous microbial populations was qualitatively and quantitatively determined and compared. In both horizons, the incubation at $4{ }^{\circ} \mathrm{C}$ is characterized by a shift in the PL inventory to more short chain fatty acids. A significant trend in the proportions of saturated and unsaturated fatty acids, however, was not detected. A higher proportion of both short chain and unsaturated fatty acids counterbalances the effect of decreasing cell membrane fluidity with decreasing environmental temperature. Thus, the adaptation of the permafrost microbial populations within the different horizons to varying ambient temperature conditions appears to be mainly regulated by the chain length of the phospholipid fatty acids. Although there is almost no change in the proportions of unsaturated fatty acids between the 4 and $28{ }^{\circ} \mathrm{C}$ incubation experiments, the permafrost-near horizon in general contains more unsaturated fatty acids than the surface-near horizon and a higher proportion of short chain fatty acids. This suggests that the lipid inventory of the microbial population nearer to the perennially frozen ground is more adapted to lower temperatures than that of the microbial community from the surface-near horizon, which seems to show a higher flexibility toward higher temperature conditions. The permafrost-near horizon appears to be dominated by psychrophilic species, while the surface-near horizon is characterized by a mesophilic-dominated microbial community.
\end{abstract}

(C) 2009 Elsevier GmbH. All rights reserved.

Keywords: Phospholipids; Microorganisms; Temperature adaptation; Permafrost environment; Lena Delta

\footnotetext{
${ }^{*}$ Corresponding author. Tel.: + 493312881785 ; fax: +493312881782 .

E-mail address: K.Mangelsdorf@gfz-potsdam.de (K. Mangelsdorf).
}

\section{Introduction}

Thanks to recent improvements in sensitivity of conventional biogeochemical and microbiological analytical methods and the development of new approaches, microbial life has been detected in environments supposed for long to be hostile (Rothschild and 
Mancinelli, 2001). The finding of microbial populations in environments like polar- and permafrost areas, hot surface springs and deep-sea hydrothermal vents, hypersaline and deep water lakes, mines and oil reservoirs, the deep sea and the deep subsurface of the Earth changed the perspective on the limits of life drastically (e.g. Kashefi and Lovley, 2003; L'Haridon et al., 1995; Liebner et al., 2009; Nisbet and Sleep, 2001; Parkes et al., 2000; Pedersen, 2000; Sharma et al., 2002; Stetter et al., 1990). In addition to pressure, nutrient availability, salinity and alkalinity, ambient temperature is one of the most important environmental factors influencing the evolution of microbial life.

Permafrost is a common feature in polar regions covering about $25 \%$ of the northern hemisphere's land surface (Zhang et al., 1999) and can extend to several hundreds of meters depth (e.g. $600-800 \mathrm{~m}$ in East Siberia). Due to the relatively short summer season in permafrost regions only the surface zone thaws. This socalled active layer is characterized by an extreme temperature regime from about +15 to $-35^{\circ} \mathrm{C}$, in which a diverse range of microorganisms have been discovered (Kobabe et al., 2004; Liebner et al., 2008). Permafrost soils are a significant source of the climaterelevant trace gas methane (Wagner et al., 2003; Wille et al., 2008). Therefore, permafrost and its microbial communities (e.g. methane producers and consumers) are of specific interest in predicting how the carbon balance of northern ecosystem will respond to climate change. There are only a few studies on microbial diversity (structure and function) in permafrost environments (see Wagner, 2008 and references therein), indicating the need for a comprehensive inventory of these habitats.

Microorganisms are able to inhabit environments with temperature conditions ranging from below $0{ }^{\circ} \mathrm{C}$ up to $121^{\circ} \mathrm{C}$ (Blöchl et al., 1995, 1997, Rothschild and Mancinelli, 2001; Kashefi and Lovley, 2003, Wagner et al., 2007). Thus, microorganisms must show a high adaptability towards extremely variable ambient temperature conditions. Sinensky (1974) introduced the theory of homeoviscous adaptation. This concept states that microorganisms change their cell membrane lipid composition in order to maintain the cell membrane fluidity and functionality in response to ambient temperature changes. To maintain the membrane fluidity in cold environments microbial cells have to keep their solid-liquid phase transition temperatures ( $T_{\mathrm{c}}$, melting temperature) below the ambient temperature. Thus, the energy supply by ambient temperature is always high enough to keep the cell membranes in a liquid stage. In order to adapt to low-temperature conditions, there are several mechanisms known for bacteria and archaea to alter their cell membrane composition accordingly (Russell and Fukunaga, 1990; Suutari and Laakso, 1994). In bacterial cell membranes, largely formed by phospholipids bilayers (phospholipid (PL) structures, see Appendix 1), commonly two main mechanisms are observed with decreasing environmental temperatures: (1) an increase in the degree of cis-unsaturated phospholipid fatty acids (PLFAs) and (2) a higher proportion of short chain phospholipid fatty acids (Suutari and Laakso, 1994). Rather rarely a raise in the proportion of larger and repulsive phospholipid head groups can be observed at lower ambient temperatures (Boggs, 1986). The incorporation of cis double bonds into the phospholipid fatty acid side chains causes a decrease in the melting temperature of the corresponding phospholipid (Russell, 1989; Coolbear et al., 1983), because cis-unsaturation inserts a kink in the otherwise relatively straight fatty acid side chains, preventing a higher compaction of the cell membrane lipids caused by decreasing ambient temperatures (Russell, 1989). A higher proportion of short chain phospholipid fatty acids also leads to a lowering of the cell membrane melting temperature (Suutari and Laakso, 1994), because of the physical effect that the melting temperatures of fatty acyl side chains decreases with decreasing chain length. Additionally, a higher relative proportion of larger and repulsive head groups lowers the melting temperatures again by preventing an increased cell membrane compaction (Boggs, 1986). Thus, the chemical structure of the different phospholipid groups effects the solid to liquid phase transition temperature of the cell membrane in response to ambient temperature changes (Russell, 1989; Chintalapati et al., 2004).

In the current study, we investigated temperaturedependent changes in the phospholipid cell membrane inventory of two microbial populations from different depth horizons of the active layer from Siberian permafrost environment. Samples of both horizons were incubated at 4 and $28^{\circ} \mathrm{C}$ and changes in the phospholipid composition were monitored using a high performance liquid chromatography coupled to a mass spectrometer (HPLC-MS) via an electrospray interface (ESI) and collisionally activated dissociation (CAD) experiments (MS-MS).

\section{Study area}

The study area Samoylov Island is located in the southern central Lena Delta in Northeast Siberia (Fig. 1). With $29,000 \mathrm{~km}^{2}$ (Schneider et al., 2009) the Lena Delta forms the second largest delta of the Arctic Ocean. The whole delta is located within the continuous permafrost zone and the landscape is dominated by ice-wedge polygons in different evolutional stages (Schwamborn et al., 2002). The Lena Delta is affected by a dry continental Arctic climate characterized by a 


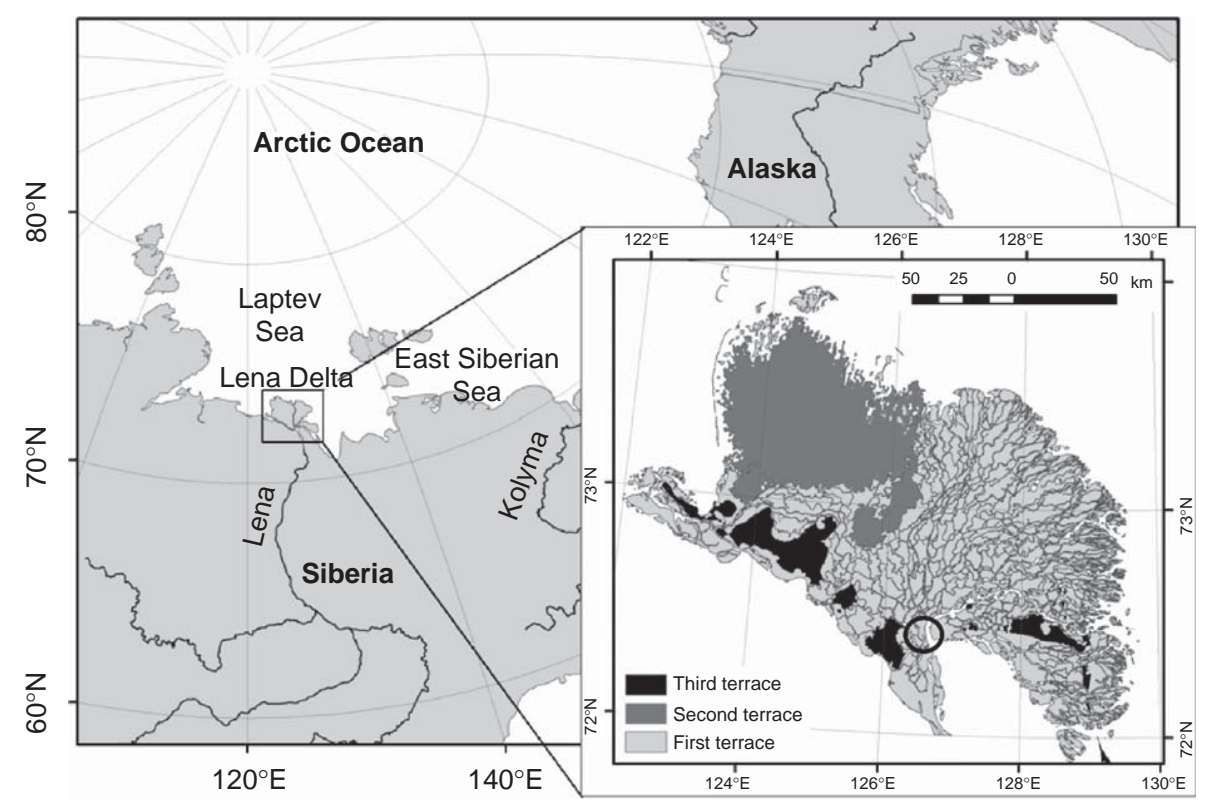

Fig. 1. Location of the Lena Delta in NE Siberia. The subset map shows the distribution of the three main geomorphologic terraces in the delta (based on Schwamborn et al., 2002) with the location of the study area Samoylov Island (black circle).

low mean annual air temperature $\left(-14.8^{\circ} \mathrm{C}\right)$ and a summer precipitation of about $200 \mathrm{~mm}$ (HMCR, 2004). The winter season lasts 8 months, from the end of September to the end of May $\left(T_{\text {avg }}=-30{ }^{\circ} \mathrm{C}\right.$, $T_{\min }=-48^{\circ} \mathrm{C}$ ) with insufficient light (polar night) and heavy snowstorms up to $140 \mathrm{~km} \mathrm{~h}^{-1}$ (Wein, 1999). The summer period of almost 12 weeks is characterized by moderate temperatures $\left(T_{\mathrm{avg}}=7{ }^{\circ} \mathrm{C}, T_{\max }=18^{\circ} \mathrm{C}\right)$ and by continuous daylight (polar day).

Samoylov Island $\left(72^{\circ} 22^{\prime} \mathrm{N}, 126^{\circ} 28^{\prime} \mathrm{E}\right)$ is located in the southern active part of the Lena Delta in one of the main channels, the Olenyok-channel (Fig. 1). Soil and vegetation characteristics of the investigation area show great variation over small distances owing to the geomorphological situation of the polygonal tundra (Fiedler et al., 2004; Kutzbach et al., 2004). The soils are characterized by very homogeneously spread soil units. The studied soil of the polygon rim was classified as a Glacic Aquiturbel (Soil Survey Staff, 1998). This relatively dry soil is characterized by a soil texture of silty and loamy sand (in this case more from fluvial than aeolian sedimentation), pronounced cryoturbation properties, a distinctly low water level causing oxic conditions in the top soil and a reduced organic matter accumulation (Fiedler et al., 2004). This is reflected by comparatively lower contents of total organic carbon $(2.1-3.3 \%)$ and an average of dissolved organic carbon of $8.7 \mathrm{mg} \mathrm{l}^{-1}$ (Wagner et al., 2003, 2005). Low temperature and insufficiency of nitrogen $\left(N_{\mathrm{t}}\right.$ ranged from 0.2 to $\left.1.4 \mathrm{~g} \mathrm{~kg}^{-1}\right)$ and phosphor $\left(P_{\mathrm{t}}\right.$ ranged from 0.47 to $0.63 \mathrm{mg} \mathrm{kg}^{-1}$ ) led to restricted production of phytomass (Fiedler et al., 2004). The vegetation of the rim is dominated by the dwarf shrub Dryas punctata and the mosses Hylocomium splendens and Timmia austriaca, whereas the adjacent polygon depression is dominated by hydrophytes like various Carex species and different moss species (e.g. Limprichtia revolvens, Meesia longiseta; Kutzbach et al., 2004). During the sampling period in August 2005, the thaw depth of the active layer amounted to about 40 and $55 \mathrm{~cm}$ in the rim and in the depression, respectively (Wagner, pers. comm.).

\section{Materials and methods}

\subsection{Sample material}

The investigated soil samples were taken during the expedition LENA 2005 from the active layer of a lowcentred ice-wedge polygon (details of patterned ground and cryogenic structure in Wagner, 2008) on Samoylov Island $\left(77^{\circ} 22^{\prime} \mathrm{N}, 126^{\circ} 28^{\prime} \mathrm{E}\right.$; Schirrmeister et al., 2007). Samples were taken by an active layer steel corer (diameter $=5.6 \mathrm{~cm}$, length $=60 \mathrm{~cm}$ ) from the rim of a polygon. The cores were frozen immediately after sampling and were transported in a frozen state for further processing to Potsdam, Germany. In the laboratory, core samples were sectioned under sterile conditions and sub-samples for phospholipid analyses were taken from the surface-near horizons $(11-18 \mathrm{~cm})$ and from the permafrost-near horizon $(32-38 \mathrm{~cm})$. Phospholipids are relatively unstable due to early diagenetic alteration and therefore are used as marker for viable microbial organisms (White et al., 1979; Harvey et al., 1986; Zink et al., 2003). To avoid potential 
phospholipids from fresh plant material the upper $11 \mathrm{~cm}$ were discarded. The active layer, which is thawed in summer and refreezed in autumn, is in the thawed stage characterized by a distinct temperature gradient from the surface to the permafrost interface ranging from 15 to $1{ }^{\circ} \mathrm{C}$.

\subsection{Incubation of permafrost soil samples}

The two soil horizons (surface- and permafrost-near horizon) were homogenised and two aliquots of $5 \mathrm{~g}$ of each horizon (three parallels) were placed in different sterile serum flasks. After addition of $5 \mathrm{ml}$ MilliQ-water the flasks were shaken for $20 \mathrm{~s}$. Finally, the soil samples were incubated at 4 and $28{ }^{\circ} \mathrm{C}$ for 3 weeks. These temperatures were chosen due to the results of microbial activity measurements, which indicated a mesophilicdominated community in the top soil of the study site, while near the permafrost table a psychrophilic community is dominating (Liebner and Wagner, 2007).

\subsection{Analytical procedure}

After the incubation, the soil material was extracted with an organic solvent mixture and the organic extracts were separated by column chromatography into fractions of different polarity. The obtained phospholipid fraction was analysed for intact phospholipids using high performance liquid chromatography mass spectrometry (HPLC-MS). For the structural elucidation of individual phospholipids, especially the fatty acyl side chain inventory, collisionally activated dissociation MSMS experiments were performed. Details on the analytical procedures and instrument conditions applied are described in Zink and Mangelsdorf (2004). For quantification of phospholipids (head group and acyl side chain inventory) obtained from the different soil horizons incubated at different temperatures, phospholipids were quantified under consideration of different response factors for individual phospholipid groups during the LC-MS detection process. Details on the relative quantification of phospholipids using HPLCMS/MS were described in Mangelsdorf et al. (2005).

\section{Results}

\subsection{Qualitative analysis of the phospholipid inventory}

The membrane phospholipid (PL) signal of the microbial populations of the different soil horizons investigated consisted of phosphatidylglycerol (PG), phosphatidylethanolamine (PE), phosphatidylmonomethylethanolamine (PMME) and phosphatidylcholine (PC) esters (Table 1, for structures see Appendix 1). This corresponds to the PL composition of microbial pure cultures from this area also containing PG, PE, PMME and PC esters (data not shown).

The dominating PL in the surface-near horizon at both incubation temperatures $\left(4\right.$ and $28^{\circ} \mathrm{C}$ ) were PCs followed by PMMEs, PGs and finally PEs. Linked saturated and mono-unsaturated fatty acids ranged from 14 to 19 carbon atoms for PGs, 14-18 for PEs, 13-20 for PMMEs and 15-20 for PCs (Table 2). While PGs and PEs covered an intermediate range of fatty acids side chain combinations $\left(\mathrm{C}_{30}-\mathrm{C}_{36}\right.$ and $\mathrm{C}_{29}-\mathrm{C}_{36}$, respectively), PCs comprised the higher end range from $\mathrm{C}_{31}$ to $\mathrm{C}_{38}$. PMMEs covered the broadest range of combinations from $\mathrm{C}_{28}$ to $\mathrm{C}_{38}$.

In contrast, the permafrost-near horizon incubations were dominated by PMMEs closely followed by PCs and to a lesser extent by PGs and PEs (Table 1). The fatty acid ranges of the individual PL groups were comparable with those of the surface-near horizon. However, $\mathrm{C}_{13}$ fatty acids were not detected (Table 3 ). The range of fatty acid combinations was also comparable, but diversity of fatty acid combinations within this range was lower. A qualitative difference of the lipid inventory between the 28 and $4{ }^{\circ} \mathrm{C}$ incubations within each horizon was not detected (Tables 2 and 3 ).

\subsection{Quantitative analysis of the phospholipid inventory}

Comparing the 28 and $4{ }^{\circ} \mathrm{C}$ incubations of the surfacenear horizon, it is shown that the relative percentage proportion of PCs decreased by $6.5 \%$ from $62.7 \%$ to

Table 1. Percentage proportions of different phospholipid groups of the total phospholipid signal of the microbial population in the surface-near and permafrost-near soil horizons incubated at 4 and $28^{\circ} \mathrm{C}$.

\begin{tabular}{|c|c|c|c|c|}
\hline \multirow[t]{2}{*}{ Phospholipid group } & \multicolumn{2}{|c|}{ Surface-near horizon $(11-18 \mathrm{~cm})$} & \multicolumn{2}{|c|}{ Permafrost-near horizon $(25-32 \mathrm{~cm})$} \\
\hline & $28^{\circ} \mathrm{C}(\%)$ & $4{ }^{\circ} \mathrm{C}(\%)$ & $28^{\circ} \mathrm{C}(\%)$ & $4{ }^{\circ} \mathrm{C}(\%)$ \\
\hline PG & 10.2 & 11.1 & 9.9 & 9.7 \\
\hline $\mathrm{PE}$ & 5.9 & 6.2 & 6.2 & 6.1 \\
\hline PMME & 21.1 & 26.5 & 43.1 & 50.0 \\
\hline PC & 62.7 & 56.2 & 40.7 & 34.3 \\
\hline
\end{tabular}

$\mathrm{PG}=$ phosphatidylglycerol; $\mathrm{PE}=$ phosphatidylethanolamine; $\mathrm{PMME}=$ phosphatidylmonomethylethanolamine; $\mathrm{PC}=$ phosphatidylcholine. 
Table 2. Fatty acid combinations linked to the different phospholipid groups of the total phospholipid signal of the microbial population in the surface-near soil horizon incubated at 4 and $28^{\circ} \mathrm{C}$.

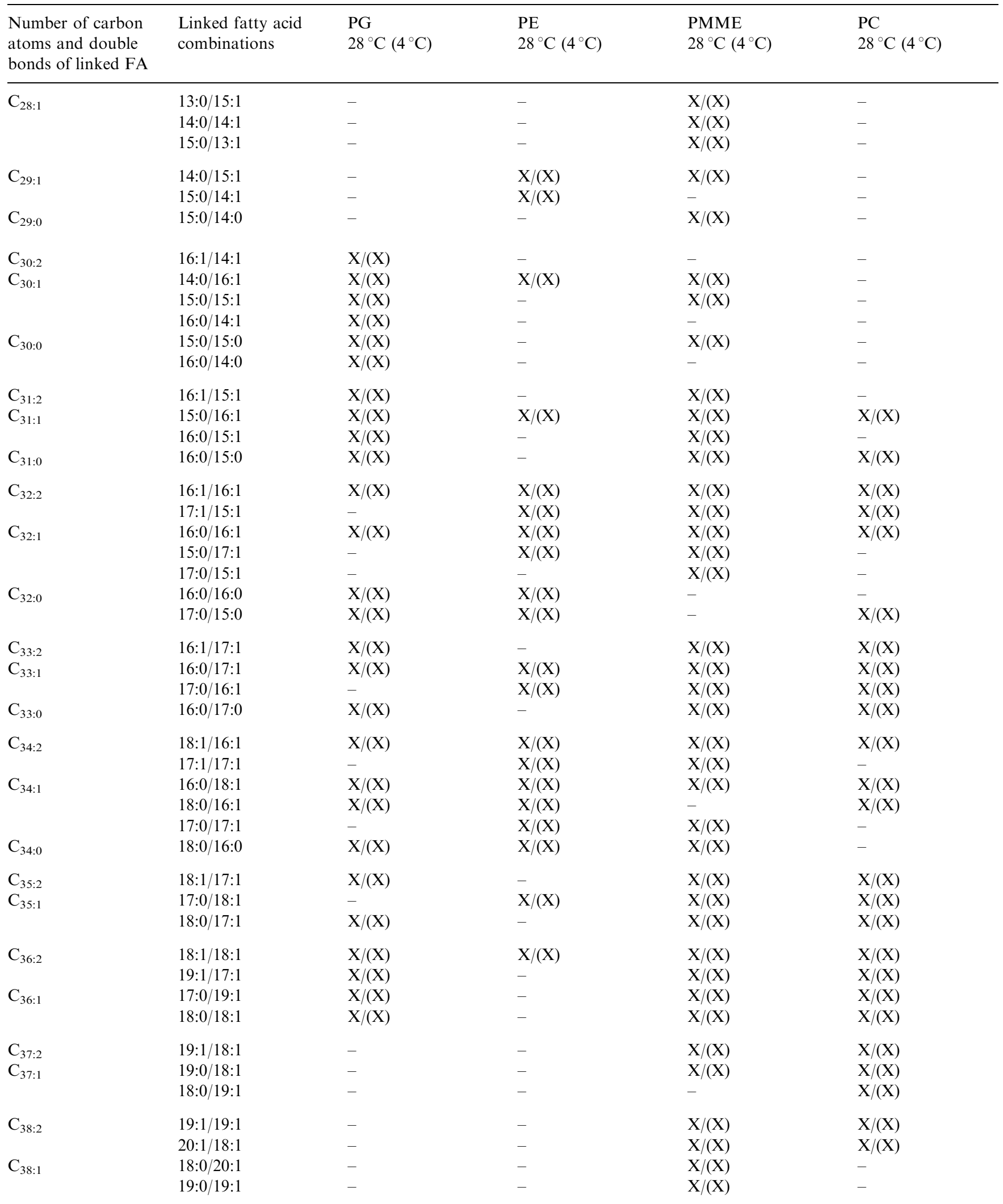

$\mathrm{PG}=$ phosphatidylglycerol; $\quad \mathrm{PE}=$ phosphatidylethanolamine $; \quad \mathrm{PMME}=$ phosphatidylmonomethylethanolamine $; \quad \mathrm{PC}=$ phosphatidylcholine. $\mathrm{FA}=$ fatty acids. 
Table 3. Fatty acid combinations linked to the different phospholipid groups of the total phospholipid signal of the microbial population in the permafrost-near soil horizon incubated at 4 and $28^{\circ} \mathrm{C}$.

\begin{tabular}{|c|c|c|c|c|c|}
\hline $\begin{array}{l}\text { Number of carbon } \\
\text { atoms and double } \\
\text { bonds of linked FA }\end{array}$ & $\begin{array}{l}\text { Linked fatty acid } \\
\text { combinations }\end{array}$ & $\begin{array}{l}\mathrm{PG} \\
28^{\circ} \mathrm{C}\left(4^{\circ} \mathrm{C}\right)\end{array}$ & $\begin{array}{l}\mathrm{PE} \\
28^{\circ} \mathrm{C}\left(4^{\circ} \mathrm{C}\right)\end{array}$ & $\begin{array}{l}\text { PMME } \\
28^{\circ} \mathrm{C}\left(4^{\circ} \mathrm{C}\right)\end{array}$ & $\begin{array}{l}\mathrm{PC} \\
28^{\circ} \mathrm{C}\left(4^{\circ} \mathrm{C}\right)\end{array}$ \\
\hline $\mathrm{C}_{28: 1}$ & $14: 0 / 14: 1$ & - & - & $\mathrm{X} /(\mathrm{X})$ & - \\
\hline $\mathrm{C}_{29: 1}$ & $\begin{array}{l}14: 0 / 15: 1 \\
15: 0 / 14: 1\end{array}$ & $\begin{array}{l}- \\
-\end{array}$ & $\begin{array}{l}\mathrm{X} /(\mathrm{X}) \\
\mathrm{X} /(\mathrm{X})\end{array}$ & $\begin{array}{l}\mathrm{X} /(\mathrm{X}) \\
-\end{array}$ & $\begin{array}{l}- \\
-\end{array}$ \\
\hline $\mathrm{C}_{29: 0}$ & $15: 0 / 14: 0$ & - & - & $\mathrm{X} /(\mathrm{X})$ & - \\
\hline $\mathrm{C}_{30: 1}$ & $\begin{array}{l}14: 0 / 16: 1 \\
15: 0 / 15: 1 \\
16: 0 / 14: 1\end{array}$ & $\begin{array}{l}\mathrm{X} /(\mathrm{X}) \\
\mathrm{X} /(\mathrm{X}) \\
\mathrm{X} /(\mathrm{X})\end{array}$ & $\begin{array}{l}\mathrm{X} /(\mathrm{X}) \\
- \\
-\end{array}$ & $\begin{array}{l}\mathrm{X} /(\mathrm{X}) \\
\mathrm{X} /(\mathrm{X}) \\
-\end{array}$ & $\begin{array}{l}- \\
- \\
-\end{array}$ \\
\hline $\mathrm{C}_{30: 0}$ & $\begin{array}{l}\text { 15:0/15:0 } \\
16: 0 / 14: 0\end{array}$ & $\begin{array}{l}\mathrm{X} /(\mathrm{X}) \\
\mathrm{X} /(\mathrm{X})\end{array}$ & $\begin{array}{l}\mathrm{X} /(\mathrm{X}) \\
\mathrm{X} /(\mathrm{X})\end{array}$ & $\begin{array}{l}\mathrm{X} /(\mathrm{X}) \\
-\end{array}$ & $\begin{array}{l}- \\
-\end{array}$ \\
\hline $\begin{array}{l}\mathrm{C}_{31: 2} \\
\mathrm{C}_{31: 1}\end{array}$ & $\begin{array}{l}16: 1 / 15: 1 \\
15: 0 / 16: 1 \\
16: 0 / 15: 1\end{array}$ & $\begin{array}{l}- \\
- \\
-\end{array}$ & $\begin{array}{l}- \\
\mathrm{X} /(\mathrm{X}) \\
-\end{array}$ & $\begin{array}{l}\mathrm{X} /(\mathrm{X}) \\
\mathrm{X} /(\mathrm{X}) \\
\mathrm{X} /(\mathrm{X})\end{array}$ & $\begin{array}{l}- \\
- \\
-\end{array}$ \\
\hline $\mathrm{C}_{32: 2}$ & $\begin{array}{l}16: 1 / 16: 1 \\
17: 1 / 15: 1\end{array}$ & $\begin{array}{l}\mathrm{X} /(\mathrm{X}) \\
-\end{array}$ & $\begin{array}{l}\mathrm{X} /(\mathrm{X}) \\
\mathrm{X} /(\mathrm{X})\end{array}$ & $\begin{array}{l}\mathrm{X} /(\mathrm{X}) \\
\mathrm{X} /(\mathrm{X})\end{array}$ & $\begin{array}{l}\mathrm{X} /(\mathrm{X}) \\
\mathrm{X} /(\mathrm{X})\end{array}$ \\
\hline $\mathrm{C}_{32: 1}$ & $\begin{array}{l}16: 0 / 16: 1 \\
15: 0 / 17: 1 \\
17: 0 / 15: 1\end{array}$ & $\begin{array}{l}\mathrm{X} /(\mathrm{X}) \\
- \\
-\end{array}$ & $\begin{array}{l}\mathrm{X} /(\mathrm{X}) \\
\mathrm{X} /(\mathrm{X}) \\
-\end{array}$ & $\begin{array}{l}\mathrm{X} /(\mathrm{X}) \\
\mathrm{X} /(\mathrm{X}) \\
\mathrm{X} /(\mathrm{X})\end{array}$ & $\begin{array}{l}\mathrm{X} /(\mathrm{X}) \\
- \\
-\end{array}$ \\
\hline $\mathrm{C}_{32: 0}$ & $\begin{array}{l}16: 0 / 16: 0 \\
17: 0 / 15: 0\end{array}$ & $\begin{array}{l}\mathrm{X} /(\mathrm{X}) \\
\mathrm{X} /(\mathrm{X})\end{array}$ & $\begin{array}{l}\mathrm{X} /(\mathrm{X}) \\
\mathrm{X} /(\mathrm{X})\end{array}$ & $\begin{array}{l}- \\
-\end{array}$ & $\begin{array}{l}- \\
-\end{array}$ \\
\hline $\begin{array}{l}\mathrm{C}_{33: 2} \\
\mathrm{C}_{33: 1}\end{array}$ & $\begin{array}{l}16: 1 / 17: 1 \\
16: 0 / 17: 1 \\
17: 0 / 16: 1\end{array}$ & $\begin{array}{l}- \\
\mathrm{X} /(\mathrm{X}) \\
-\end{array}$ & $\begin{array}{l}- \\
\mathrm{X} /(\mathrm{X}) \\
\mathrm{X} /(\mathrm{X})\end{array}$ & $\begin{array}{l}\mathrm{X} /(\mathrm{X}) \\
- \\
-\end{array}$ & $\begin{array}{l}- \\
\mathrm{X} /(\mathrm{X}) \\
\mathrm{X} /(\mathrm{X})\end{array}$ \\
\hline $\mathrm{C}_{33: 0}$ & $16: 0 / 17: 0$ & $\mathrm{X} /(\mathrm{X})$ & - & - & - \\
\hline $\mathrm{C}_{34: 2}$ & $\begin{array}{l}18: 1 / 16: 1 \\
17: 1 / 17: 1\end{array}$ & $\begin{array}{l}\mathrm{X} /(\mathrm{X}) \\
-\end{array}$ & $\begin{array}{l}\mathrm{X} /(\mathrm{X}) \\
\mathrm{X} /(\mathrm{X})\end{array}$ & $\begin{array}{l}\mathrm{X} /(\mathrm{X}) \\
\mathrm{X} /(\mathrm{X})\end{array}$ & $\begin{array}{l}\mathrm{X} /(\mathrm{X}) \\
-\end{array}$ \\
\hline $\mathrm{C}_{34: 1}$ & $\begin{array}{l}16: 0 / 18: 1 \\
18: 0 / 16: 1 \\
17: 0 / 17: 1\end{array}$ & $\begin{array}{l}- \\
- \\
-\end{array}$ & $\begin{array}{l}\mathrm{X} /(\mathrm{X}) \\
\mathrm{X} /(\mathrm{X}) \\
\mathrm{X} /(\mathrm{X})\end{array}$ & $\begin{array}{l}\mathrm{X} /(\mathrm{X}) \\
- \\
\mathrm{X} /(\mathrm{X})\end{array}$ & $\begin{array}{l}\mathrm{X} /(\mathrm{X}) \\
\mathrm{X} /(\mathrm{X}) \\
-\end{array}$ \\
\hline $\mathrm{C}_{35: 2}$ & $18: 1 / 17: 1$ & - & - & $\mathrm{X} /(\mathrm{X})$ & $\mathrm{X} /(\mathrm{X})$ \\
\hline $\mathrm{C}_{36: 2}$ & $\begin{array}{l}18: 1 / 18: 1 \\
19: 1 / 17: 1\end{array}$ & $\begin{array}{l}\mathrm{X} /(\mathrm{X}) \\
\mathrm{X} /(\mathrm{X})\end{array}$ & $\begin{array}{l}\mathrm{X} /(\mathrm{X}) \\
-\end{array}$ & $\begin{array}{l}\mathrm{X} /(\mathrm{X}) \\
\mathrm{X} /(\mathrm{X})\end{array}$ & $\begin{array}{l}\mathrm{X} /(\mathrm{X}) \\
\mathrm{X} /(\mathrm{X})\end{array}$ \\
\hline $\begin{array}{l}\mathrm{C}_{37: 2} \\
\mathrm{C}_{37: 1}\end{array}$ & $\begin{array}{l}19: 1 / 18: 1 \\
19: 0 / 18: 1 \\
18: 0 / 19: 1\end{array}$ & $\begin{array}{l}- \\
- \\
-\end{array}$ & $\begin{array}{l}- \\
- \\
-\end{array}$ & $\begin{array}{l}- \\
- \\
-\end{array}$ & $\begin{array}{l}\mathrm{X} /(\mathrm{X}) \\
\mathrm{X} /(\mathrm{X}) \\
\mathrm{X} /(\mathrm{X})\end{array}$ \\
\hline $\mathrm{C}_{38: 2}$ & $\begin{array}{l}\text { 19:1/19:1 } \\
20: 1 / 18: 1\end{array}$ & $\begin{array}{l}- \\
-\end{array}$ & $\begin{array}{l}- \\
-\end{array}$ & $\begin{array}{l}\mathrm{X} /(\mathrm{X}) \\
\mathrm{X} /(\mathrm{X})\end{array}$ & $\begin{array}{l}\mathrm{X} /(\mathrm{X}) \\
\mathrm{X} /(\mathrm{X})\end{array}$ \\
\hline
\end{tabular}

$\mathrm{PG}=$ phosphatidylglycerol; $\quad \mathrm{PE}=$ phosphatidylethanolamine $; \quad \mathrm{PMME}=$ phosphatidylmonomethylethanolamine; $\quad \mathrm{PC}=$ phosphatidylcholine. $\mathrm{FA}=$ fatty acids

$56.2 \%$ (Table 1 ). This was mainly counterbalanced by an increase of PMMEs from $21.1 \%$ to $26.5 \%$, while PGs and PEs remained relatively constant. A comparable picture can be observed in the 28 and $4{ }^{\circ} \mathrm{C}$ incubations of the permafrost-near horizon. PCs decreased by $6.4 \%$ from $40.7 \%$ to $34.3 \%$ and PMMEs increased from $43.1 \%$ to $50 \%$, while PGs and PEs remained constant with comparable percentages as in the surface-near horizon (Table 1). Thus, both horizons showed the same shifts during the temperature experiments. The main difference was that the surface-near horizon was dominated by PCs and the permafrost-near horizon by PMMEs.

The quantitative distribution of the fatty acyl side chain inventory of the surface-near microbial population incubated at 4 and $28^{\circ} \mathrm{C}$ is shown in Fig. $2 \mathrm{a}$ and $\mathrm{b}$. 

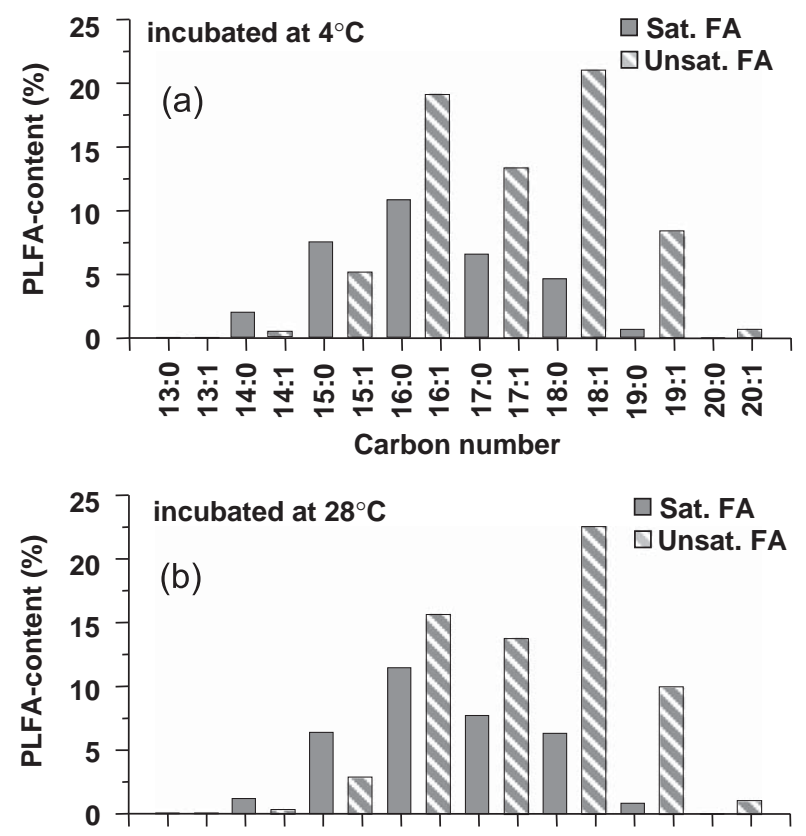

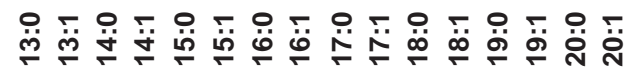

Carbon number

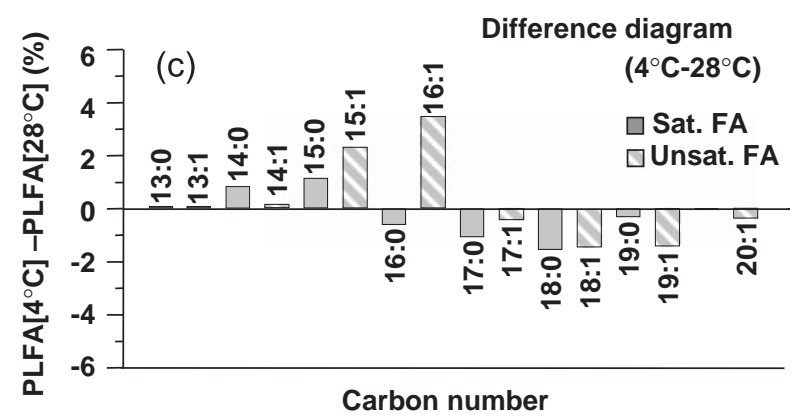

Fig. 2. Phospholipid fatty acid (PLFA) side chain distribution of the microbial community from the surface-near horizon incubated at $4{ }^{\circ} \mathrm{C}$ (a) and $28^{\circ} \mathrm{C}$ (b). Difference diagram (c) of the fatty acid distribution incubated at 4 and $28^{\circ} \mathrm{C}$. Unsat. and sat. $\mathrm{FA}=$ unsaturated and saturated fatty acids. $x: y=$ carbon number:number of double bonds.
For better visualization of the changes in the fatty acyl side chain inventory between both incubation experiments a difference diagram was created by subtracting the fatty acid distribution at $28^{\circ} \mathrm{C}$ from that at $4{ }^{\circ} \mathrm{C}$ (Fig. 2c). It can be recognized that the fatty acid inventory of the $4{ }^{\circ} \mathrm{C}$ incubation was composed of less long chain fatty acids and more short chain fatty acids. A clear shift from $37.9 \%\left(28{ }^{\circ} \mathrm{C}\right.$ incubation $)$ to $45.1 \%$ $\left(4{ }^{\circ} \mathrm{C}\right.$ incubation) of $7.2 \%$ to more short chain fatty acids is discernable, whereas the percentage proportions of saturated and unsaturated fatty acids did not change significantly (Table 4).

The quantitative distribution of the fatty acyl side chain inventory of the permafrost-near microbial population incubated at 4 and $28{ }^{\circ} \mathrm{C}$ is shown in Fig. $3 \mathrm{a}$ and $\mathrm{b}$. The same trend to more short chain fatty acids in the $4{ }^{\circ} \mathrm{C}$ incubation can be observed. This shift was somewhat larger $(10.3 \%)$ than in the surfacenear horizon (Table 4). The relative proportions of saturated and unsaturated fatty acids remained also relatively constant during the incubation experiments.

However, with $73.2 \%$ and $72.2 \%$ the permafrost-near microbial population contained on average about $5.7 \%$ more unsaturated fatty acids than the surface-near population. With $50.1 \%$ and $60.4 \%$ it also contained about $12-15 \%$ more short chain fatty acids compared to the population of the surface-near horizon with $37.9 \%$ and $45.1 \%$ (Table 4 ).

A deeper insight into the membrane alteration during the temperature experiments for both horizons is provided by Figs. 4 and 5 . In these figures, the relative proportions of the individual PL groups on the total fatty acid side chain inventory (Figs. 2 and 3) are presented. Both figures revealed a minor influence of the PG and PE signals on the total fatty acid distribution, although a trend towards more short chain fatty acids was discernable in the PG signal of the surface-near horizon (Fig. 4). Main changes derived from the alteration of the PC and PMME lipid inventory as

Table 4. Percentage proportions of unsaturated and saturated phospholipid fatty acids (PLFAs) and short chain $\left(\mathrm{C}_{13}-\mathrm{C}_{16}\right)$ and long chain $\left(\mathrm{C}_{17}-\mathrm{C}_{20}\right)$ PLFAs of the microbial population in the surface-near and permafrost-near soil horizons incubated at 4 and $28^{\circ} \mathrm{C}$.

\begin{tabular}{|c|c|c|c|c|}
\hline \multirow[t]{2}{*}{ Parameter } & \multicolumn{2}{|c|}{ Surface-near horizon $(11-18 \mathrm{~cm})$} & \multicolumn{2}{|c|}{ Permafrost-near horizon $(25-32 \mathrm{~cm})$} \\
\hline & $28^{\circ} \mathrm{C}(\%)$ & $4^{\circ} \mathrm{C}(\%)$ & $28^{\circ} \mathrm{C}(\%)$ & $4{ }^{\circ} \mathrm{C}(\%)$ \\
\hline Unsat. FA & 66.1 & 67.9 & 73.2 & 72.2 \\
\hline Sat. FA & 33.9 & 32.1 & 26.8 & 27.8 \\
\hline $\mathrm{C}_{17}-\mathrm{C}_{20} \mathrm{FA}$ (long) & 62.1 & 54.9 & 49.9 & 39.6 \\
\hline $\mathrm{C}_{13}-\mathrm{C}_{16} \mathrm{FA}$ (short) & 37.9 & 45.1 & 50.1 & 60.4 \\
\hline
\end{tabular}

Unsat. FA = unsaturated fatty acids; Sat. FA = saturated fatty acids. 

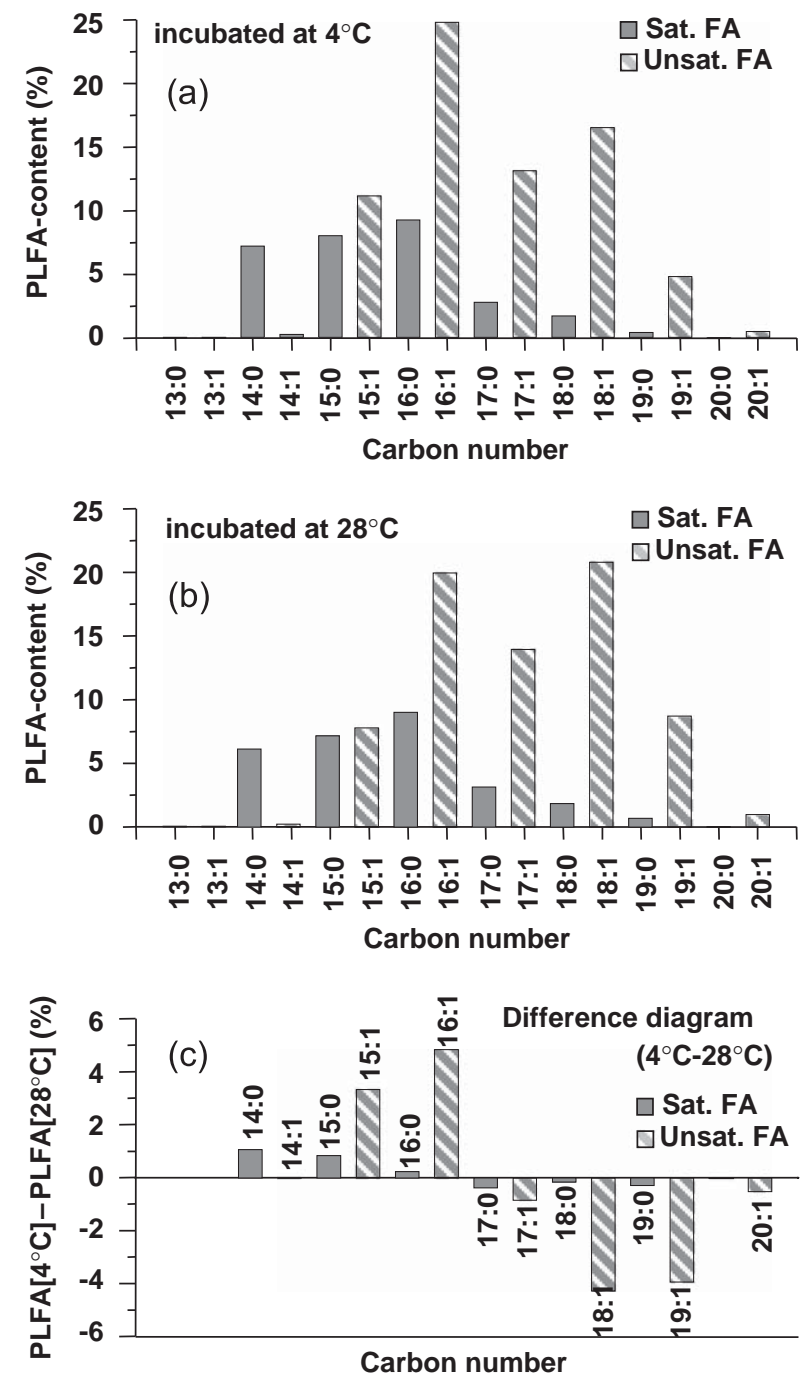

Fig. 3. Phospholipid fatty acid (PLFA) side chain distribution of the microbial community from the permafrost-near horizon incubated at $4{ }^{\circ} \mathrm{C}$ (a) and $28^{\circ} \mathrm{C}$ (b). Difference diagram (c) of the fatty acid distribution incubated at 4 and $28^{\circ} \mathrm{C}$. Unsat. and sat. $\mathrm{FA}=$ unsaturated and saturated fatty acids. $x: y=$ carbon number:number of double bonds.

already suggested from Table 1. Long chain fatty acids were preferentially lost during the decrease of PCs between the 28 and $4{ }^{\circ} \mathrm{C}$ incubation in both horizons. The increase of short chain fatty acids in the $4{ }^{\circ} \mathrm{C}$ incubations in both horizons was predominantly linked to the relative increase of PMMEs.

\section{Discussion}

The seasonal unfrozen part of the permafrost landscape (active layer, approximately $0.5 \mathrm{~m}$ soil depth at the study site) is subjected to freezing and thawing cycles during the year with a large temperature gradient between 15 and $1{ }^{\circ} \mathrm{C}$ along their depth profile in the thawed stage. This temperature gradient is one of the main environmental factors influencing microorganisms in permafrost-affected soils. The phospholipid inventory used for the characterization of the adaptation of microorganisms to the low in situ temperature of their extreme habitat showed significant differences in the relative phospholipid composition between active layer surface- and permafrost-near horizons, on the one hand, and between the 4 and $28^{\circ} \mathrm{C}$ incubation experiments, on the other hand.

\subsection{Changes in the phospholipid head group composition}

The PL signal of the surface-near microbial population is dominated by PCs, while that of the permafrostnear microbial community is dominated by PMMEs. The relative proportion of PGs and PEs is quite similar in both horizons and seem to show no significant temperature-dependent variability. In contrast, both horizons reveal an increase of PMMEs in the $4{ }^{\circ} \mathrm{C}$ incubation. Thus, the observed trend in both temperature incubation experiments together with the dominance of PMMEs in the indigenous microbial population nearer to the perennially frozen ground suggests a shift to more PMMEs at lower temperature conditions in this permafrost environment.

It is suggested that larger head groups like those of the PGs and PCs cause a greater disturbance of the cell membrane compaction than the smaller PE head group. Additionally, PEs are able to interact intermolecularly by way of hydrogen-bonding leading to a higher membrane compaction (Boggs, 1986; Russell, 1989; Fang et al., 2000). The phase transition temperatures of PG (16:0/16:0) and PC (16:0/16:0) being both ca. $41{ }^{\circ} \mathrm{C}$ are about $20^{\circ} \mathrm{C}$ lower than that of PE (16:0/16:0) with a value of ca. $63{ }^{\circ} \mathrm{C}$ (Cullis et al., 1996). The corresponding PMME, the mono- $N$-methylated congener of $\mathrm{PE}$, shows with $\mathrm{ca} .58^{\circ} \mathrm{C}$ a phase transition temperature between those of the PC (tri- $N$-methylated PE) and PE (Casal and Mantsch, 1983). Thus, membrane phase transition temperature decreases in a series from $\mathrm{PE}>\mathrm{PMME}>\mathrm{PC}=\mathrm{PG}$.

Considering this the observed shift to more PMMEs at lower temperature conditions seems to contradict the concept of incorporating more of larger and repulsive head groups to lower the phase transition temperature. However, according to the phospholipid side chain analyses (Tables 2 and 3) it can be deduced that PCs only cover the higher end of fatty acid combinations $\left(\mathrm{C}_{31}-\mathrm{C}_{38}\right)$ with a maximum at $\mathrm{C}_{18}$ (Figs. 4 and 5). In contrast, PMMEs cover the broadest range of combinations $\left(\mathrm{C}_{28}-\mathrm{C}_{38}\right)$ including many short chain fatty acid combinations and a maximum at $\mathrm{C}_{16}$ (Figs. 4 and 5). 

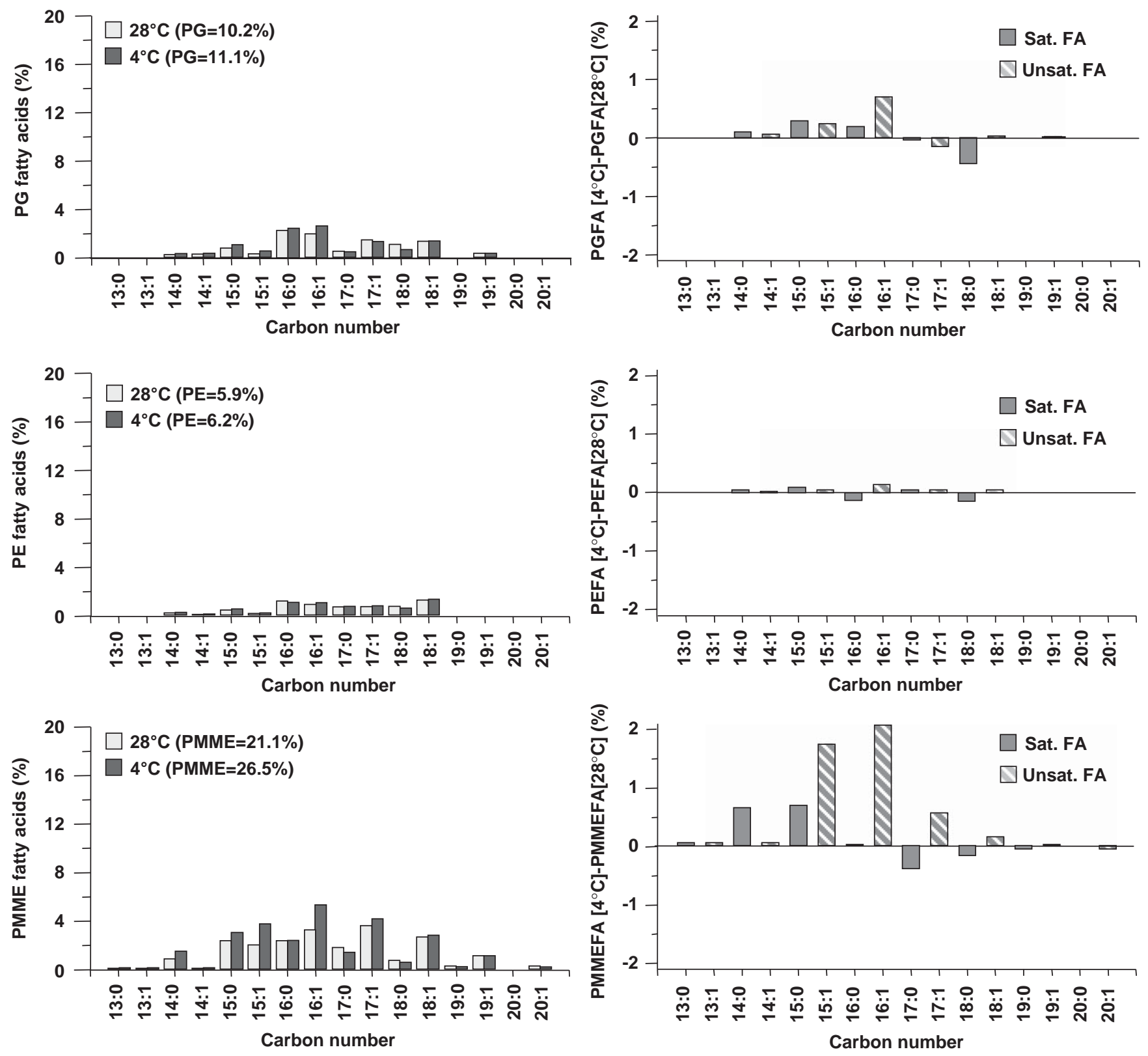

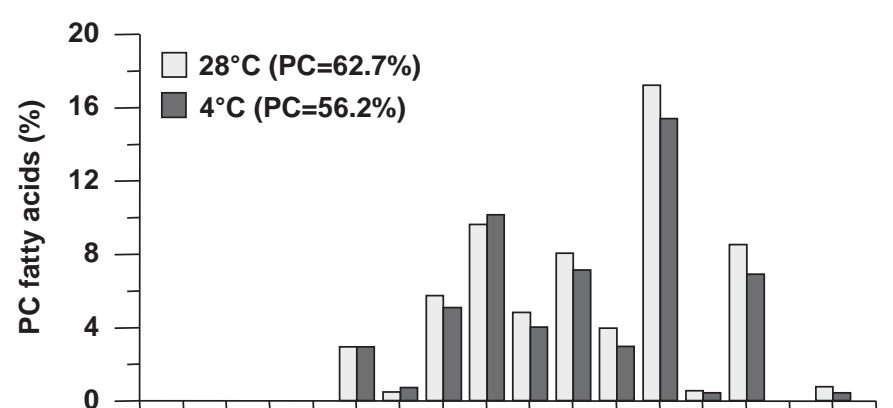

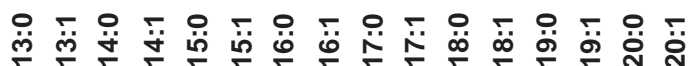

Carbon number

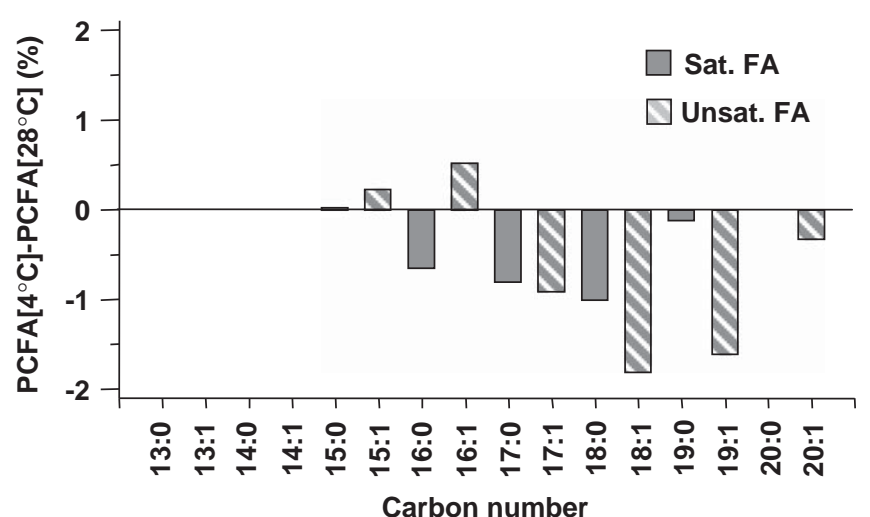

Carbon number

Fig. 4. Fatty acid distribution pattern of phosphatidylglycerols (PGs), phosphatidylethanolamines (PEs), phosphatidylmonomethylethanolamines (PMMEs) and phosphatidylcholines (PCs) in their percentage proportion of the total fatty acid distribution of the microbial population from the surface-near horizon incubated at 4 and $28^{\circ} \mathrm{C}$. Difference diagram of the fatty acid distribution of individual phospholipid groups in their percentage proportion incubated at 4 and $28^{\circ} \mathrm{C}$. Unsat. and sat. FA $=$ unsaturated and saturated fatty acids. $x: y=$ carbon number:number of double bonds. 

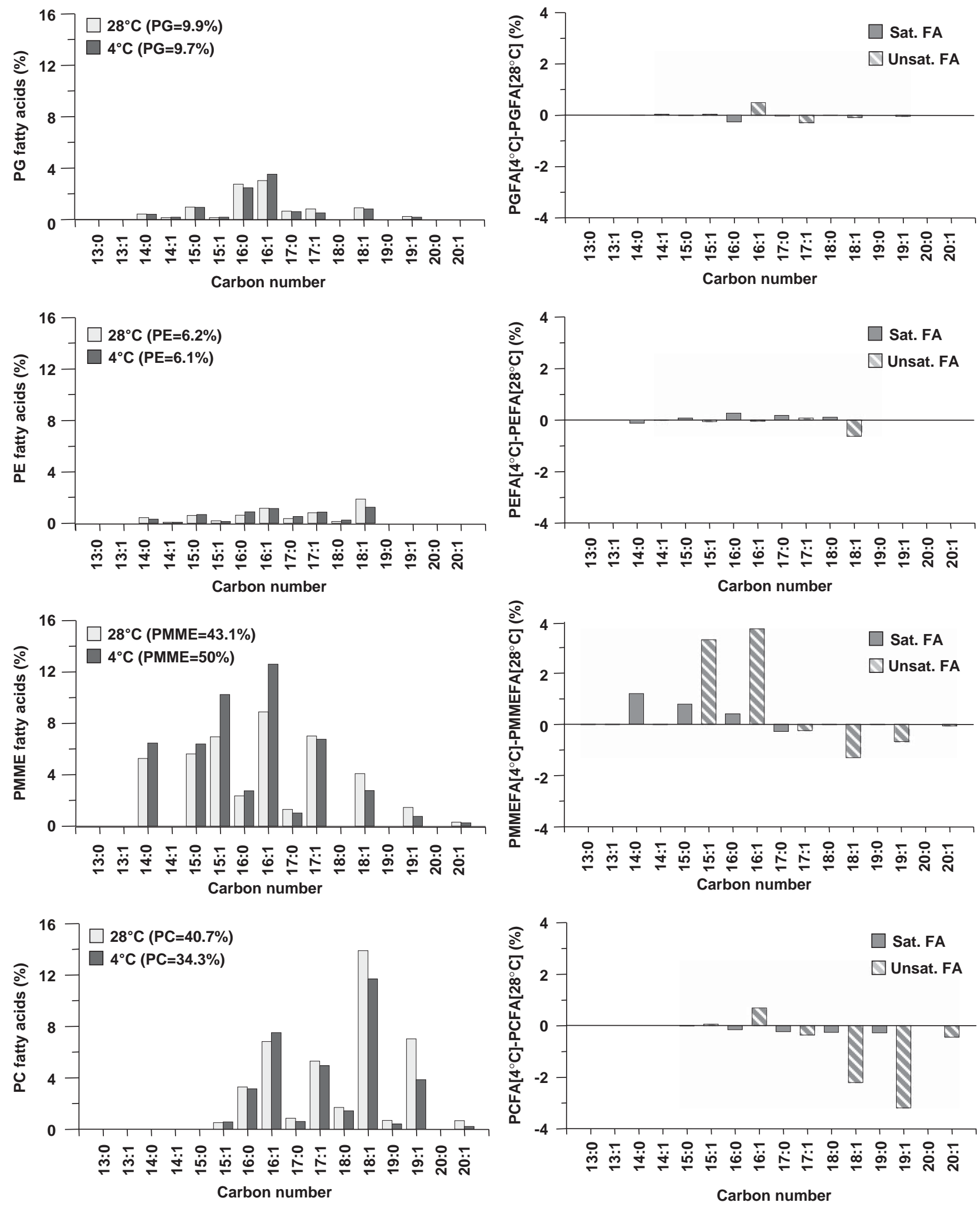

Fig. 5. Fatty acid distribution pattern of phosphatidylglycerols (PGs), phosphatidylethanolamines (PEs), phosphatidylmonomethylethanolamines (PMMEs) and phosphatidylcholines (PCs) in their percentage proportion of the total fatty acid distribution of the microbial population from the permafrost-near horizon incubated at 4 and $28^{\circ} \mathrm{C}$. Difference diagram of the fatty acid distribution of individual phospholipid groups in their percentage proportion incubated at 4 and $28{ }^{\circ} \mathrm{C}$. Unsat. and sat. $\mathrm{FA}=$ unsaturated and saturated fatty acids. $x: y=$ carbon number:number of double bonds. 
The incorporation of more short chain fatty acid combinations is an important adaptation in lowtemperature environments to keep the phase transition temperatures below the ambient temperature (see below). Thus, these data suggest that the relative proportions of head groups are not determined by their effect directly on the cell membrane fluidity but rather by the spectrum of fatty acids linked to the different PL groups.

\subsection{Ratio of unsaturated to saturated phospholipid fatty acids}

A higher proportion of cis-unsaturated fatty acids also leads to a decrease of the phase transition temperature of cell membranes (Cossins, 1983), because the bended configuration of the cis-unsaturated phospholipid fatty acid side chain prevents a closer cell membrane packing. In fact, cis-unsaturation causes a pronounced decrease of the phase transition temperature $\left(\mathrm{PC}(18: 0 / 18: 0)=55.8^{\circ} \mathrm{C}\right.$ and $\mathrm{PC}(18: 0 / 18: 1)=$ $6.3^{\circ} \mathrm{C}$; from Russell, 1989).

In both horizons, saturated and mono-unsaturated fatty acids were detected, which is common for bacteria (Russell and Fukunaga, 1990). Poly-unsaturated fatty acids as often observed in response to higher ambient pressure (DeLong and Yayanos, 1985; Yano et al., 1998; Nogi and Kato, 1999) were not detected. High pressure and low temperature seem to cause comparable compositional membrane lipid adaptations. The incorporation of one double bond has the largest effect on the solid-liquid phase transition temperature and more than 2 double bonds appear to have the opposing effect by increasing the rigidity of the fatty acyl chains (Coolbear et al., 1983; Suutari and Laakso, 1994). The PL signals of the surface-near as well as of the permafrost-near horizon reveal both a high content of mono-unsaturated fatty acids (on average $67 \%$ and $72.7 \%$, respectively) indicating a high adaptation to the low-temperature conditions in permafrost areas. On average, the permafrost-near horizon reveals $5.7 \%$ more unsaturated fatty acids than the surface-near horizon. Thus, the microbial population nearer to the perennially frozen ground seems to show a higher adaptation to cooler ambient conditions.

Comparing the temperature experiments there is no significant change in the ratio between saturated and unsaturated fatty acids. Although Figs. 2 and 3 show an increase of short chain unsaturated fatty acids, this is concomitantly outweighed by the loss of long chain unsaturated fatty acids. Thus, surprisingly the microbial communities within the different depth horizons seem not to alter their degree of unsaturation significantly as an adaptation to lower ambient temperatures.

\subsection{Ratio of short chain to long chain phospholipid fatty acids}

A shortening of the chain length of the phospholipid fatty acids also causes a decrease in the melting temperatures of the PLs (Russell, 1989). For instance, the phase transition temperature of the PC (16:0/14:0) is with $27^{\circ} \mathrm{C}$ about $14{ }^{\circ} \mathrm{C}$ lower than that of the PC $(16: 0 /$ 16:0) with $41{ }^{\circ} \mathrm{C}$ and about $28^{\circ} \mathrm{C}$ lower than that of the PC (18:0/18:0) with $55^{\circ} \mathrm{C}$ (Keough and Davis, 1979; Russell, 1989; Cullis et al., 1996). Thus, the shift to shorter fatty acid forms another microbial adaptation mechanism to maintain the cell membrane fluidity.

The permafrost-near horizon shows a $12-15 \%$ higher proportion of short chain fatty acids than the surfacenear horizon, indicating again a higher adaptation of the permafrost-near microbial population to the lower temperatures adjacent to the perennially frozen ground. The $4{ }^{\circ} \mathrm{C}$ temperature incubation experiments reveal for both horizons a significant increase of short chain fatty acids associated to the alteration from less PCs to more PMMEs (Figs. 4 and 5), whereas this trend is somewhat larger within the permafrost-near microbial community (Table 4). This suggests that within the investigated horizons the maintenance of the cell membrane fluidity at decreasing ambient temperature conditions is mainly regulated by the chain length of the phospholipid fatty acids.

\subsection{Origin for the compositional changes of the phospholipid inventory}

These results raise the question where the observed compositional changes of the phospholipid cell membrane inventories originate from: a direct restructuring of the cell membranes of the indigenous microbial community during the 3 weeks of incubation or a relative preferential increase (dominance) of specific microbes especially adapted to the different incubation temperature conditions.

Liebner and Wagner (2007) reported that the permafrost soil samples contain overall a mixture of mesophilic and psychrophilic microbes, whereas the surface-near horizon is dominated by mesophilic and the permafrost-near part by psychrophilic microorganisms. A trend of the overall composition of the microbiota along an in situ temperature gradient in permafrost soils of the active layer is supported by a study of Liebner et al. (2008). They showed a shift of the bacterial community along the soil profile by clone library analysis. Particularly, the Bacteroidetes-Chlorobi phylum drastically increased with increasing soil depth. This group is characterized by psychrophilic species (Shivaji et al., 1991). This suggests that the general difference in the phospholipid distribution between the 
(a) PG:<smiles>[R]C(=O)OCC(COP(=O)(O)OCC(O)CO)OC([R])=O</smiles>

(c) PMME:<smiles>[R]C(=C)OC(COC([R])=O)COP(=O)(O)OCCN([2H])C</smiles>

(b) PE:<smiles>[R]C(=O)OCC(COP(=O)(O)OCCN)OC([R])=O</smiles>

(d) PC:<smiles>[R]C(=O)OCC(COP(=O)([O-])OCC[N+](C)(C)C)OC([R])=O</smiles>

Fig. 6. Molecular structure of the different phospholipid groups detected in the soil sediments of the current study: (a) $\mathrm{PG}=$ phosphatidylglycerol; (b) $\mathrm{PE}=$ phosphatidylethanolamine; (c) PMME = phosphatidylmonomethylethanolamine; $\mathrm{PC}=$ phosphatidylcholine. $R_{1}$ and $R_{2}=$ saturated or unsaturated alkyl side chains with various numbers of carbon atoms.

permafrost-near and surface-near microbial communities (more short chain and unsaturated phospholipid fatty acid side chains in the permafrost-near population) are caused by different proportions of mesophilic (higher in surface-near horizon) and psychrophilic (higher in permafrost-near horizon) microbial species in the two horizons investigated (Table 4).

Within the different horizons, the compositional changes during the 4 and $28^{\circ} \mathrm{C}$ incubation experiments might also partly derive from a relative increase of mesophilic microorganisms in the $28{ }^{\circ} \mathrm{C}$ incubation and psychrophilic species in the $4^{\circ} \mathrm{C}$ incubation. However, the fact that only a shift to more short chain phospholipid fatty acid side chains can be observed during the temperature experiments and not also to more unsaturated fatty acid side chains (Table 4) points to an additional adaptive restructuring of the cell membrane lipid composition within the mesophilic and psychrophilic species in response to the ambient temperature conditions.

\section{Conclusions}

The aim of the current study was to examine as to how the microbial populations within the different horizons of the active layer were adapted to the extreme variable temperature regime of the permafrost-affected soils. Therefore, two soil samples were taken from the active layer on Samoylov Island in the southern central Lena Delta, Siberia and aliquots of each sample were incubated under 4 and $28^{\circ} \mathrm{C}$.

The comparison of the phospholipid fatty acid distribution of the incubation experiments within the surface-near and the permafrost-near horizons shows no significant change in the proportion of unsaturated fatty acids under cold temperature conditions $\left(4{ }^{\circ} \mathrm{C}\right)$ in comparison to higher temperatures $\left(28^{\circ} \mathrm{C}\right)$. In contrast to this finding the surface-near as well as the permafrostnear microbial communities reveal both a distinct relative increase of short chain fatty acids of $7.3 \%$ and $10.3 \%$, respectively, after an incubation at $4{ }^{\circ} \mathrm{C}$. As fatty acids with shorter chain length lower the solid-liquid phase transition temperatures of the corresponding phospholipid, these results indicate that the adaptation towards lower ambient temperatures is mainly regulated by a higher proportion of short chain phospholipid fatty acid side chains.

In addition to this significant chain length adaptation, the PLFA proportions of the microbial population of the active layer differ between the surface-near and permafrost-near horizon. The microbial community closer to the perennially frozen ground shows in general a higher relative proportion of unsaturated and shorter chain fatty acids. This indicates a stronger adaptation to cold in situ temperature (constantly $<2{ }^{\circ} \mathrm{C}$ ), whereas the surface-near population appears to reveal a higher flexibility towards warmer temperature conditions.

It is suggested that the general compositional changes in the phospholipid inventories between both horizons derived from a relative dominance of mesophilic species in the surface-near and psychrophilic species in the permafrost-near horizon. However, the 4 and $28^{\circ} \mathrm{C}$ incubation experiments also suggest that an adaptive restructuring of the cell membrane composition within the mesophilic and psychrophilic communities in response to environmental temperature conditions is additionally responsible for the compositional changes in the phospholipid membrane inventory. 


\section{Acknowledgements}

The authors acknowledge the crew of the expedition LENA 2005, in particular Waldemar Schneider for logistic and Günter 'Molo' Stoof for technical support (both Alfred Wegener Institute for Polar and Marine Research). We also want to thank all our Russian partners, in particular, Dimitry Yu. Bolshiyanov (Arctic Antarctic Research Institute), Alexander Yu. Dereviagin (Moscow State University), Mikhail N. Grigoriev (Permafrost Institute, Yakutsk), Dmitri V. Melnitschenko (Hydro Base Tiksi) and Alexander Yu. Gukov (Lena Delta Reserve). We are also grateful to two anonymous reviewers for their helpful comments. Finally, we would like to thank the Helmholtz Association for financial support of this study.

\section{Appendix 1}

Fig. 6.

\section{References}

Blöchl, E., Burggraf, S., Fiala, G., Lauerer, G., Huber, G., Huber, R., Rachel, R., Segerer, A., Stetter, K.O., Völkl, P., 1995. Isolation, taxonomy and phylogeny of hyperthermophilic microorganisms. World Journal of Microbiological Biotechnology 11, 9-16.

Blöchl, E., Rachel, R., Burggraf, S., Hafenbradl, D., Jannasch, H.W., Stetter, K.O., 1997. Pyrolobus fumarii, gen. and sp. nov., represents a novel group of archaea, extending the upper temperature limit for life to $113^{\circ} \mathrm{C}$. Extremophiles 1, $14-21$.

Boggs, J.M., 1986. Effect of lipid structural modifications on their intermolecular hydrogen bonding interactions and membrane functions. Canadian Journal of Biochemistry and Cell Biology 64, 50-57.

Casal, H.L., Mantsch, H.H., 1983. The thermotrophic phase behaviour of $N$-methylated dipalmitoylphosphatidylethanolamines. Biochimica et Biophysica Acta 735, 387-396.

Chintalapati, S., Kiran, M.D., Shivaji, S., 2004. Role of membrane lipid fatty acids in cold adaptation. Cellular and Molecular Biology 50, 631-642.

Coolbear, K.P., Berde, C.B., Keough, K.M.W., 1983. Gel to liquid-crystalline phase transitions of aqueous dispersions of polyunsaturated mixed-acid phosphatidylcholines. Biochemistry 22, 1466-1473.

Cossins, A.R., 1983. The adaptation of membrane structure and function to changes in temperature. In: Cossins, A.R., Sherterline, P. (Eds.), Cellular Acclimatisation to Environmental Changes. Cambridge University Press, Cambridge, pp. 3-32.

Cullis, P., Fenske, D.B., Hope, M.J., 1996. Physical properties and functional roles of lipids in membranes. In: Vance, D.E., Vance, J.E. (Eds.), Biochemistry of Lipids,
Lipoproteins and Membranes. New Comprehensive Biochemistry. Elsevier, Amsterdam, pp. 1-33.

DeLong, E.F., Yayanos, A.A., 1985. Adaptation of membrane lipids of deep-sea bacterium to changes in hydrostatic pressure. Science 228, 1101-1103.

Fang, J., Barcelona, M.J., Nogi, Y., Kato, C., 2000. Biochemical implications and geochemical significance of novel phospholipids of the extremely barophilic bacteria from the Marianas Trench at 11,000 m. Deep-Sea Research 47, 1173-1182.

Fiedler, S., Wagner, D., Kutzbach, L., Pfeiffer, E.M., 2004. Element redistribution along hydraulic and redox gradients of low-centered polygons, Lena Delta, Northern Siberia. Soil Science Society of America Journal 68, 1002-1011.

Harvey, H.R., Fallon, R., Patton, J.S., 1986. The effect of organic matter and oxygen on the degradation of bacterial membrane lipids in marine sediments. Geochemica et Cosmochimica Acta 50, 795-804.

HMCR, Hydrometeorological Centre of Russia, 2004. Russia's Weather, 〈http://meteo.infospace.ru $\rangle$.

Kashefi, K., Lovley, D.R., 2003. Extending the upper temperature limit of life. Science 301, 934.

Keough, K.M.W., Davis, P.J., 1979. Gel to liquid-crystalline phase transition in water dispersions of saturated mixedacid phosphatidylcholines. Biochemistry 18, 1453-1459.

Kobabe, S., Wagner, D., Pfeiffer, E.-M., 2004. Characterization of microbial community composition of a Siberian tundra soil by fluorescence in situ hybridization. FEMS Microbiology Ecology 50, 13-23.

Kutzbach, L., Wagner, D., Pfeiffer, E.-M., 2004. Effects of microrelief and vegetation on methane emission from wet polygonal tundra, Lena Delta, Northern Siberia. Biogeochemistry $69,341-362$.

L'Haridon, S., Reysenbach, A.-L., Glénat, P., Prieur, D., Jeanthon, C., 1995. Hot subterranean biosphere in continental oil reservoir. Nature 377, 223-224.

Liebner, S., Wagner, D., 2007. Abundance, distribution and potential activity of methane oxidising bacteria in permafrost soils from the Lena Delta, Siberia. Environmental Microbiology 9, 107-117.

Liebner, S., Rublack, K., Stuehrmann, T., Wagner, D., 2009. Diversity of aerobic methanotrophic bacteria in a permafrost active layer soil of the Lena Delta, Siberia. Microbial Ecology 57, 25-35.

Liebner, S., Harder, J., Wagner, D., 2008. Bacterial diversity and community structure in polygonal tundra soils from Samoylov Island, Lena Delta, Siberia. International Microbiology 11, 195-202.

Mangelsdorf, K., Zink, K.-G., Birrien, J.-L., Toffin, L., 2005. A quantitative assessment of pressure dependent adaptive changes in the membrane lipids of a piezosensitive deep sub-seafloor bacterium. Organic Geochemistry 36, 1459-1479.

Nisbet, E.G., Sleep, N.H., 2001. The habitat and nature of early life. Nature 409, 1083-1091.

Nogi, Y., Kato, C., 1999. Taxonomic studies of extremely barophilic bacteria isolated from the Mariana Trench and description of Mortitella yayanosii sp. nov., a new barophilic bacterial isolate. Extremophiles 3, 71-77. 
Parkes, R.J., Cragg, B.A., Wellsbury, P., 2000. Recent studies on bacterial populations and processes in subseafloor sediments: a review. Hydrogeology Journal 8, 11-28.

Pedersen, K., 2000. Exploration of deep intraterrestrial microbial life: current perspectives. FEMS Microbiology Letters 185, 9-16.

Rothschild, L.J., Mancinelli, R.L., 2001. Life in extreme environments. Nature 409, 1092-1101.

Russell, N.J., 1989. Functions of lipids: structural roles and membrane functions. In: Ratledge, C., Wilkinson, S.G. (Eds.), Microbial Lipids 2. Academic Press, London, pp. 279-365.

Russell, N.J., Fukunaga, N., 1990. A comparison of thermal adaptation of membrane lipids in psychrophilic and thermophilic bacteria. FEMS Microbiological Reviews 75, 171-182.

Schirrmeister, L., Wagner, D., Grigoriev, M.N., Bolshiyanov, D.Y., 2007. Russian-German cooperation system Laptev sea 2000: the expedition LENA 2005. Reports on Polar and Marine Research 550, 289pp.

Schneider, J., Grosse, G., Wagner, D., 2009. Land cover classification of tundra environments in the Arctic Lena Delta based on Landsat 7 ETM + data and its application for upscaling of methane emissions. Remote Sensing of Environment 113, 380-391.

Schwamborn, G., Rachold, V., Grigoryev, M., 2002. Late Quaternary sedimentation history of the Lena Delta. Quaternary International 89, 119-134.

Sharma, A., Scott, J.H., Cody, G.D., Fogel, M.L., Hazen, R.M., Hemley, R.J., Huntress, W.T., 2002. Microbial activity at gigapascal pressures. Science 295, 1514-1516.

Shivaji, S., Ray, M.K., Rao, N.S., Saisree, L., Jagannadham, M.V., Kumar, M.V., Reddy, G.S.N., Bhargava, P.M., 1991. Sphingobacterium antarcticus sp. nov. a psychrotrophic bacterium from the soils of Schirmacher Oasis, Antarctica. International Journal of Systematic Bacteriology 42, 102-106.

Sinensky, M., 1974. Homeoviscous adaptation - a homeostatic process that regulates the viscosity of membrane lipids in Escherichia coli. Proceedings of the National Academy of Science USA 71, 522-525.

Soil Survey Staff, 1998. Keys to Soil Taxonomy, eighth ed. Blacksburgs, Virginia, USA (Soil Conservation Service, USDA, Pocahontas).

Stetter, K.O., Fiala, G., Huber, G., Segerer, R., 1990. Hyperthermophilic microorganisms. FEMS Microbiology Reviews 75, 117-124.
Suutari, M., Laakso, S., 1994. Microbial fatty acids and thermal adaptation. Critical Reviews in Microbiology 20, 285-328.

Wagner, D., Kobabe, S., Pfeiffer, E.-M., Hubberten, H.-W., 2003. Microbial controls on methane fluxes from a polygonal tundra of the Lena Delta, Siberia. Permafrost and Periglacial Processes 14, 173-185.

Wagner, D., Lipski, A., Embacher, A., Gattinger, A., 2005. Methane fluxes in extreme permafrost habitats of the Lena Delta: effects of microbial community structure and organic matter quality. Environmental Microbiology 7, $1582-1592$.

Wagner, D., Gattinger, A., Embacher, A., Pfeiffer, E.-M., Schloter, M., Lipski, A., 2007. Methanogenic activity and biomass in Holocene permafrost deposits of the Lena Delta, Siberian Arctic and its implication for the global methane budget. Global Change Biology 13, 1089-1099.

Wagner, D., 2008. Microbial communities and processes in Arctic permafrost environments. In: Dion, P., Nautiyal, C.S. (Eds.), Microbiology of Extreme Soils. Soil Biology 13. Springer, Berlin, pp. 133-154.

Wein, N., 1999. Sibirien. Perthes Regionalprofile. KlettPerthes, Gotha, 248pp.

White, D.C., Davis, W.M., Nickels, J.S., King, J.D., Bobbie, R.J., 1979. Determination of the sedimentary microbial biomass by extractible liquid phosphate. Oecologia 40, 51-62.

Wille, C., Kutzbach, L., Sachs, T., Wagner, D., Pfeiffer, E.-M., 2008. Methane emission from Siberian Arctic polygonal tundra: eddy covariance measurements and modeling. Global Change Biology 14, 1395-1408.

Yano, Y., Nakayama, A., Ishihara, K., Saito, H., 1998. Adaptive changes in membrane lipids of barophilic bacteria in response to changes in growth pressure. Applied and Environmental Microbiology 64, 479-485.

Zhang, T., Barry, R.G., Knowles, K., Hegnibottom, J.A., Brown, J., 1999. Statistics and characteristics of permafrost and ground-ice distribution in the Northern Hemisphere. Polar Geography 2, 132-154.

Zink, K.-G., Wilkes, H., Disko, U., Elvert, M., Horsfield, B., 2003. Intact phospholipids - microbial "life markers" in marine deep subsurface sediments. Organic Geochemistry 34, 755-769.

Zink, K.-G., Mangelsdorf, K., 2004. Efficient and rapid method for extraction of intact phospholipids from sediments combined with molecular structure elucidation using LC-ESI-MS-MS analysis. Analytical and Bioanalytical Chemistry 380, 798-812. 